\title{
Binding and biological effects of insulin, insulin analogues and insulin-like growth factors in rat aortic smooth muscle cells. Comparison of maximal growth promoting activities
}

\author{
K. E. Bornfeldt ${ }^{1}$, R. A. Gidlöf ${ }^{1}$, A. Wasteson ${ }^{2}$, M. Lake ${ }^{4}$, A. Skottner ${ }^{5}$ and H. J. Arnqvist ${ }^{3}$ \\ Departments of ${ }^{1}$ Pharmacology, ${ }^{2}$ Cell Biology and ${ }^{3}$ Internal Medicine, Faculty of Health Sciences, Linköping University, Linköping, \\ ${ }^{4}$ KabiGen and ${ }^{5}$ Kabi Peptide Hormones, Stockholm, Sweden
}

Summary. Binding and growth promoting effects of insulin, insulin analogues modified in the B chain, proinsulin, insulin-like growth factor-I and -II were studied in cultured rat aortic smooth muscle cells. Specific binding of ${ }^{125}$ I-insulin was $0.9 \pm 0.2 \%$ of total ${ }^{125} \mathrm{I}$-insulin added, and the $\mathrm{IC}_{50}$-value was estimated to $8.9 \mathrm{pmol} / \mathrm{l}$. The insulin analogue B10 Asp tended to be more potent than insulin in displacing ${ }^{125} \mathrm{I}$-insulin, B28 Asp was equipotent, B9 Asp/B27 Glu was approximately 100 times less potent and insulin-like growth factor-I more than 1000 times less potent than insulin. Specific binding of ${ }^{125} \mathrm{I}$-insulin-like growth factor-I after $4 \mathrm{~h}$ incubation at $10^{\circ} \mathrm{C}$ was five times higher than the specific binding of insulin $\left(4.4 \pm 0.4 \%\right.$ of total ${ }^{225}$ I-insulin-like growth factor-I added), and the $\mathrm{IC}_{50}$-value was $0.3 \mathrm{nmol} / 1$. Insulin was approximately 500 times less potent than insulin-like growth factor-I in displacing ${ }^{125} \mathrm{I}$-insulin-like growth factor-I. The insulin analogue B10 Asp was slightly more potent and analogue B28 Asp was equipotent with insulin. Analogue B9 Asp/B27 Glu was ten times less potent and proinsulin was more than ten times less potent than insulin. The order of potency was similar for ${ }^{3} \mathrm{H}$-thymidine incorporation into DNA: insulin-like growth
factor-I $>$ B10 Asp $>$ insulin-like growth factor-II $>$ insulin $\geq$ B28 Asp > B9 Asp/B27 Glu > proinsulin. The maximal effect of insulin-like growth factor-I on ${ }^{3} \mathrm{H}$-thymidine incorporation was $71 \pm 16 \%$ higher than the maximal effect of insulin. The maximal effect of insulin-like growth factor-II was at least as high as the effect of insulin-like growth factor-I. Furthermore, the maximal effect of B10 Asp was $62 \pm 10 \%$ higher than the maximal effect of insulin. Insulin-like growth factor-I and B10 Asp tended to increase cell number more than insulin. In conclusion, this study shows that insulin analogues interact with different potencies with receptors for insulin and insulin-like growth factor-I in vascular smooth muscle cells and that insulin-like growth factors and the insulin analogue B10 Asp have more pronounced growth effects than insulin. Substitution of the amino acid Asp for His at position $\mathrm{B} 10$ in insulin makes the molecule more similar to insulin-like growth factor-I, chemically and probably also biologically.

Key words: Insulin, insulin analogues, insulin-like growth factors, proliferation, vascular smooth muscle cells
Recombinant DNA technology has made it possible to synthesize insulin in large amounts, and to alter the structure of the molecule. By changing the insulin structure, insulins with favourable physico-chemical properties can be obtained. Insulin analogues modified at certain positions in the B chain do not form dimers or hexamers in concentrations used for injection [1]. These insulin analogues are absorbed faster after subcutaneous injection than the present rapid-acting insulins [1]. However, before they are used to treat patients with diabetes it is important to carefully examine their interaction with receptors and their biological effects.

The insulin receptor is structurally homologous to the insulin-like growth factor-I (IGF-I) receptor [2,3], and insulin and IGF-I crossreact with their respective receptors $[4,5]$. IGF-I, IGF-II, multiplication stimulating activity (the rat IGF-II analogue) and insulin stimulate DNA syn- thesis in cultured vascular smooth muscle cells $[4,6-9]$. A growth promoting action of insulin on the vascular smooth muscle cells has been suggested to be of importance for the development of atherosclerosis in diabetic patients $[10$, 11].

These considerations prompted the present investigation to compare the binding and growth promoting activities of insulin, the insulin analogues B10 Asp, B28 Asp and B9 Asp/B27 Glu, proinsulin and recombinant human IGFI and IGF-II in cultured rat aortic smooth muscle cells.

\section{Materials and methods}

Isolation and culturing of cells

Rat aortic smooth muscle cells were isolated and cultured according to a modified method of Nilsson et al. [12]. Small pieces of the aortas were digested for $1 \mathrm{~h}$ in $0.1 \%$ collagenase in Ham's F-12 medium 
[13], at $37^{\circ} \mathrm{C}$ and then for $18-20 \mathrm{~h}$ in fresh collagenase/F-12. The cell suspension was filtered through a nylon filter (pore size $48 \mu \mathrm{m}$, Schweizerische Seidengaze Fabrik AG, Zürich, Switzerland), and the cells were washed in F-12 medium. The cells were transferred to a solution of the following composition: F-12 medium, $10 \mathrm{mmol} / 1$ HEPES, $10 \mathrm{mmol} / 1$ TES, $50 \mu \mathrm{g} / \mathrm{ml}$ ascorbic acid, $50 \mu \mathrm{g} / \mathrm{ml}$ gentamicin sulphate, $2 \mu \mathrm{g} / \mathrm{ml}$ Fungizone and $10 \%$ newborn calf serum (pH 7.4). Cells were plated in $75 \mathrm{~cm}^{2}$ culturing flasks and kept at $37^{\circ} \mathrm{C}$ in a humidified atmosphere of $5 \% \mathrm{CO}_{2}$ in air. The medium was changed three times a week and the cells were harvested using a solution of trypsin $(0.25 \%)$ and EDTA $(0.02 \%)$. Cells from the first to fourth generation were used in the experiments. The cells were characterized as smooth muscle cells by morphological criteria [14] and with a murine antibody which recognizes a unique epitope of $\alpha$ smooth muscle actin [15]. The cells were randomly tested for mycoplasma infectión with Mycotrim TC (Hana Media Inc., Berkeley, Calif., USA). All experiments were performed on near-confluent cultures which were kept for $24 \mathrm{~h}$ in serum-free MCDB 104 medium before the experiments.

\section{Binding studies}

Near-confluent cell cultures, cultured in six-well plates, were incubated for $4 \mathrm{~h}$ at $10^{\circ} \mathrm{C}$ in HEPES binding buffer $(\mathrm{pH} 7.8)$ with the following composition (mmol/l): HEPES 100, $\mathrm{NaCl} 120, \mathrm{KCl} 5$, $\mathrm{MgSO}_{4} 1.2$, glucose 8 and $0.1 \%$ bovine serum albumin with the addition of $25,000 \mathrm{cpm}{ }^{125}$ I-IGF-I $(12.5 \mathrm{pmol} / \mathrm{l})$ or ${ }^{125}$ I-insulin (43.9 pmol/1) and unlabelled polypeptides at indicated concentrations. The cells were washed four times with ice-cold phosphate-buffered saline, and then solubilized in $0.1 \%$ sodium dodecyl sulphate (SDS). The radioactivity was measured in a gamma counter. Unspecific binding of ${ }^{125} \mathrm{I}$-insulin or ${ }^{125} \mathrm{I}$-IGF-I was defined as binding in the presence of $0.1 \mu \mathrm{mol} / /$ unlabelled insulin or IGF-I, respectively.

\section{${ }^{3} H$-thymidine incorporation into $D N A$}

DNA-synthesis was quantified by measuring ${ }^{3} \mathrm{H}$-thymidine incorporation into DNA according to a modified method of Nilsson and Thyberg [16]. The cells, grown in 24-well plates, were incubated for $24 \mathrm{~h}$ in $\mathrm{F}-12$ medium at $37^{\circ} \mathrm{C}$ with the addition of $1 \mu \mathrm{Ci} / \mathrm{ml}^{3} \mathrm{H}$-thymidine and in the absence or presence of polypeptides at indicated concentrations. DNA was precipitated with ice cold 5\% trichloroacetic acid and then solubilized in $0.5 \mathrm{ml} 0.1 \mathrm{~mol} / \mathrm{K} \mathrm{KOH}$. Part of the solution $(0.2 \mathrm{ml})$ was added to Insta-Gel, and the radioactivity was counted in a liquid scintillation counter (Rackbeta 1217, LKB Wallac, Turku, Finland). The data were expressed as per cent increase in ${ }^{3} \mathrm{H}$-thymidine incorporation over control cells, incubated in the absence of polypeptides or serum. The time-course studies were performed as above. Polypeptides were added after $24 \mathrm{~h}$ in scrum-free medium and after $6,12,16$ and $22 \mathrm{~h} 2 \mu \mathrm{Ci} / \mathrm{ml}^{3} \mathrm{H}$-thymidine was added, and the cells incubated for an additional $2 \mathrm{~h}$.

\section{Autoradiography}

DNA synthesis was also measured by autoradiography. The cells were grown on glass coverslips, while in other respects they were treated as described above. After $24 \mathrm{~h}$ of incubation the cells were fixed in a solution of $50 \mathrm{mmol} / \mathrm{l}$ sucrose $/ 3 \%$ glutaraldehyde, dehydrated and autoradiographed with Kodak $\mathrm{NTB}_{2}$ film. After an exposure time of 6 days $\left(4^{\circ} \mathrm{C}\right)$ the cells were dyed in methylene blue, as described by Nilsson et al. [17].

\section{Cell proliferation studies}

Near-confluent cell cultures were deprived of serum for $24 \mathrm{~h}$, and then incubated with serum or polypeptides in F-12 medium for $48 \mathrm{~h}$. The cells were trypsinized and counted in a Bürker chamber.

\section{IGF-I and insulin degradation}

Degradation of ${ }^{125} \mathrm{I}$-IGF-I and ${ }^{125} \mathrm{I}$-insulin was measured after $24 \mathrm{~h}$ incubation with cells treated exactly as in the DNA-synthesis experiments, in the absence or presence of different concentrations of unlabelled IGF-I or insulin. After $24 \mathrm{~h}$ the medium was collected and precipitated with an equal volume of $25 \%$ ice-cold trichloroacetic acid [18]. Trichloroacetic acid soluble radioactivity was considered as degraded peptide.

\section{Production of recombinant polypeptides}

Recombinant human IGF-I was produced in yeast as the authentic peptide [19]. The batches used $(2104,2111)$ had a specific activity of approximately 14,000 units/mg according to placental radioreceptor assay ( 1 unit is defined as the activity of $1 \mathrm{ml}$ of a normal human serum pool). Recombinant human IGF-II, identical to IGF-II isolated from human plasma, was produced as a fusion protein in Escherichia coli. The fusion protein was secreted and after cleavage the peptide was purified to $>95 \%$ purity. Insulin analogues were produced as described by Brange et al. [1]. The analogues used were analogue $\mathrm{B} 10 \mathrm{His} \rightarrow \mathrm{Asp}$, analogue $\mathrm{B} 28$ Pro $\rightarrow$ Asp and analogue B9Ser $\rightarrow$ Asp/B27Thr $\rightarrow$ Glu.

\section{Chemicals}

Human semisynthetic insulin and mono- ${ }^{125} \mathrm{I}$-(Tyr A14)-human insulin $(1500 \mathrm{Ci} / \mathrm{mmol}$ ) were obtained from Novo (Copenhagen, Denmark $) \cdot\left[6-{ }^{3} \mathrm{H}\right]$ thymidine $(5 \mathrm{Ci} / \mathrm{mmol})$ and ${ }^{125} \mathrm{I}-\mathrm{IGF}-\mathrm{I}(2000 \mathrm{Ci} / \mathrm{mmol})$ were from Amersham (Amersham, Bucks, UK). Bovine serum albumin, HEPES, TES, ascorbic acid, collagenase and gentamicin sulphate were from Sigma (St. Louis, Mo., USA). Medium F12, newborn calf serum and medium MCDB 104 were from Gibco (Paisley, UK). Fungizone was from ER Squibb \& Sons (Princeton, NJ, USA). Trypsin was from Difco Labs (Detroit, Mich., USA). Insta-Gel was obtained from Packard (Groningen, The Netherlands) and NTB film was obtained from Kodak (Stockholm, Sweden). All other chemicals were of reagent grade.

\section{Statistical analysis}

Values are given as mean \pm SEM. Levels of significance were calculated by analysis of variance or Student's $t$-test. Concentration-effect curves were treated statistically by fitting the experimental data points into the logistic function:

\section{Observed effect $=$ Maximal effect X $(D)^{q /}\left(D^{q}+E C 50^{q}\right)$}

by means of non-linear least-square regression [20], using Marquardt's algorithm for least-square regression [21]. D represents the molar concentration of the peptide and $q$ is a constant which is dependent on the slope of the curve. The logarithmic transformation of $\mathrm{EC}_{50}$ or $\mathrm{IC}_{50}\left(\mathrm{pD}_{2}\right)$ was used when standard errors were calculated according to Waud [20].

\section{Results}

\section{Binding studies}

The specific binding of ${ }^{125} \mathrm{I}$-insulin was $0.9 \pm 0.2 \%$ of total ${ }^{125} \mathrm{I}$-insulin added. The concentration needed to give halfmaximal displacement ( $\mathrm{IC}_{50}$ ) was estimated to $8.9 \mathrm{pmol} / \mathrm{l}$ $\left(\mathrm{pD}_{2}=11.0 \pm 0.1\right)$ (Fig. 1). The insulin analogue B10 Asp 


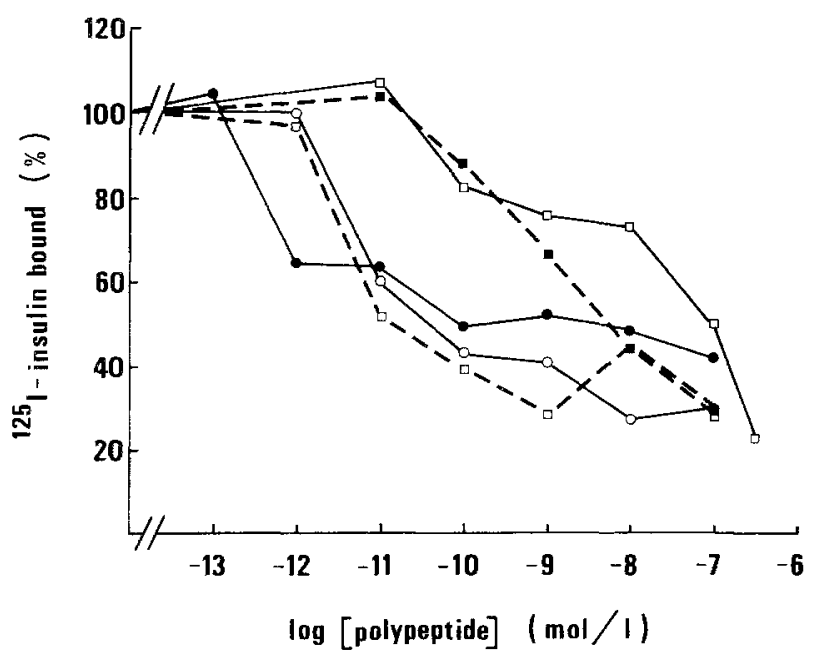

Fig. 1. Displacement of ${ }^{125}$ I-insulin ( $\left.43.9 \mathrm{pmol} / \mathrm{l}\right)$ by unlabelled insulin $(\bigcirc-0, n=5)$, insulin-like growth factor- $\mathrm{I}(\square-\square, n=5)$, analogue B10 Asp $(\bullet, n=8)$, analogue B28 Asp ( $\square-\cdots, n=5)$ and analogue B9 Asp/B27 Glu ( $\square-\cdots=5$ ). Near-confluent cells were incubated with polypeptides for $4 \mathrm{~h}\left(10^{\circ} \mathrm{C}\right)$ in Hepes-binding buffer. Values are given as mean. SEM was $2.6-25.0 \%$ of the mean value

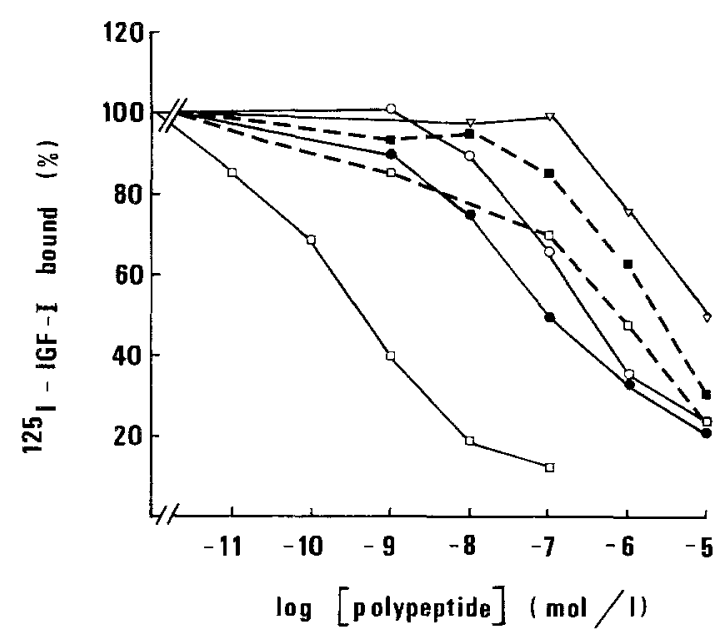

Fig. 2. Displacement of ${ }^{125}$ I-insulin-like growth factor I (IGF-I) (12.5 pmol/l) by unlabelled IGF-I ( $\square-\square)$, insulin $(\circ-0)$, analogue B10 Asp (-), analogue B28 Asp ( $\square--\square)$, analogue B9 Asp/B27 Glu ( $(\mathbf{\square - -})$ and proinsulin $(\nabla \nabla)$. Near-confluent cells were incubated with polypeptides for $4 \mathrm{~h}\left(10^{\circ} \mathrm{C}\right)$ in Hepes-binding buffer. Values are given as mean $(n=4)$. SEM was $2.7-17.1 \%$ of the mean value

tended to be more potent than insulin $\left(\mathrm{IC}_{50}=0.8 \mathrm{pmol} / \mathrm{l}\right.$, $\left.\mathrm{pD}_{2}=12.1 \pm 3.7\right), \mathrm{B} 28 \mathrm{Asp}$ was equipotent with insulin $\left(\mathrm{IC}_{50}=5.4 \mathrm{pmol} / 1, \mathrm{pD}_{2}=11.3 \pm 0.2\right), \mathrm{B} 9 \mathrm{Asp} / \mathrm{B} 27 \mathrm{Glu}$ was approximately 100 times less potent than insulin $\left(\mathrm{IC}_{50}=1.2 \mathrm{nmol} / 1, \mathrm{pD}_{2}=8.9 \pm 0.5\right)$ whereas IGF-I was more than 1000 times less potent than insulin in displacing ${ }^{125}$ I-insulin (Fig. 1).

The specific binding of ${ }^{125} \mathrm{I}-\mathrm{IGF}-\mathrm{I}$ was approximately five times higher than the specific binding of insulin ( $4.4 \pm 0.4 \%$ of total ${ }^{125} \mathrm{I}$-IGF-I added). The $\mathrm{IC}_{50}$-value was $0.3 \mathrm{nmol} / 1\left(\mathrm{pD}_{2}=9.5 \pm 0.1\right)$ as shown in Figure 2. Unlabelled insulin was approximately 500 times less potent than IGF-I $\left(\mathrm{IC}_{50}=149 \mathrm{nmol} / \mathrm{l}, \mathrm{pD}_{2}=6.8 \pm 0.3\right)$, and proinsulin was approximately 10,000 times less potent. Anal- ogue B10 Asp was slightly more potent than insulin $\left(\mathrm{IC}_{50}=76 \mathrm{nmol} / \mathrm{l}, \mathrm{pD}_{2}=7.1 \pm 0.5\right)$, analogue $\mathrm{B} 28$ Asp was equipotent, and analogue B9 Asp/B27 Glu was approximately ten times less potent than insulin to displace ${ }^{125} \mathrm{I}-$ IGF-I (Fig. 2).

\section{DNA synthesis}

Incorporation of ${ }^{3} \mathrm{H}$-thymidine into control cells, incubated for $24 \mathrm{~h}$ in the absence of polypeptides or serum was $5.1 \pm 0.4 \mathrm{nmol}$ thymidine/g protein (mean $\pm \mathrm{SEM}, n=6$ ). When the effects of IGF-I, IGF-II and insulin were compared, the mean maximal effect of IGF-I was found to be $71.0 \pm 16.4 \%$ higher than the maximal effect of insulin. The maximal effect of IGF-II was at least as high as the maximal effect of IGF-I (Fig. 3). Insulin $\left(\mathrm{EC}_{50}=29 \mathrm{nmol} / \mathrm{l}\right.$, $\left.\mathrm{pD}_{2}=7.5 \pm 0.3\right)$ and IGF-II $\left(\mathrm{EC}_{50}=15 \mathrm{nmol} / 1, \mathrm{pD}_{2}=\right.$ $7.8 \pm 0.2)$ were more than 100 times less potent than IGF-I $\left(\mathrm{EC}_{50}=0.1 \mathrm{nmol} / 1, \mathrm{pD}_{2}=9.9 \pm 0.1\right)$. The combined effects of IGF-I and IGF-II, the combined effects of IGF-I and insulin or the combined effects of IGF-II and insulin were not additive (Fig. 3).

Analogue B10 Asp $\left(\mathrm{EC}_{50}=3.0 \mathrm{nmol} / \mathrm{L}, \mathrm{pD}_{2}=8.5 \pm 0.3\right)$ was more potent than human insulin $\left(\mathrm{EC}_{50}=21 \mathrm{nmol} / \mathrm{l}\right.$, $\left.\mathrm{pD}_{2}=7.7 \pm 0.3\right)($ Fig. 4$)$ and induced a $62.1 \pm 10.3 \%$ higher maximal effect than insulin as shown in Figure 5. B28 Asp was equipotent with insulin $\left(\mathrm{EC}_{50}=70 \mathrm{nmol} / \mathrm{l}\right.$, $\mathrm{pD}_{2}=7.1 \pm 0.1$ ) and the maximal effect on DNA synthesis was equal (Fig. 4, insert). The insulin analogue B9 Asp/B27 Glu was approximately eight times less potent

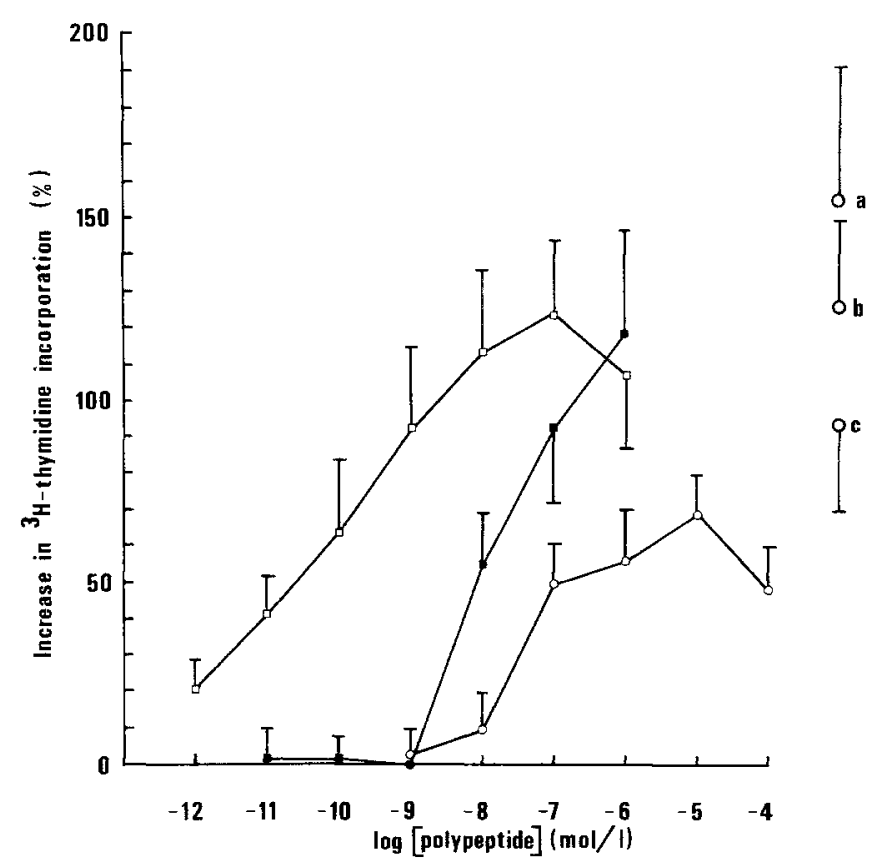

Fig. 3. Effect of insulin-like growth factor (IGF-I) ( $\square$ ), IGF-II ( and insulin (O) on ${ }^{3} \mathrm{H}$-thymidine incorporation in rat aortic smooth muscle cells. Near-confluent cell cultures were incubated at $37^{\circ} \mathrm{C}$ for $24 \mathrm{~h}$ in F-12 medium in the presence of ${ }^{3} \mathrm{H}$-thymidine and IGF-I, IGF-II and/or insulin. Combinations of $0.1 \mu \mathrm{mol} / 1 \mathrm{IGF}-\mathrm{I}$ and $0.1 \mu \mathrm{mol} / 1 \mathrm{IGF}-\mathrm{II}$ (a), $1.0 \mu \mathrm{mol} / 1$ insulin and $0.1 \mu \mathrm{mol} / 1 \mathrm{IGF}-\mathrm{I}$ (b) and $1.0 \mu \mathrm{mol} / 1$ insulin and $0.1 \mu \mathrm{mol} / \mathrm{l}$ IGF-II (c) are indicated. Values are mean $\pm \operatorname{SEM}(n=4)$ 


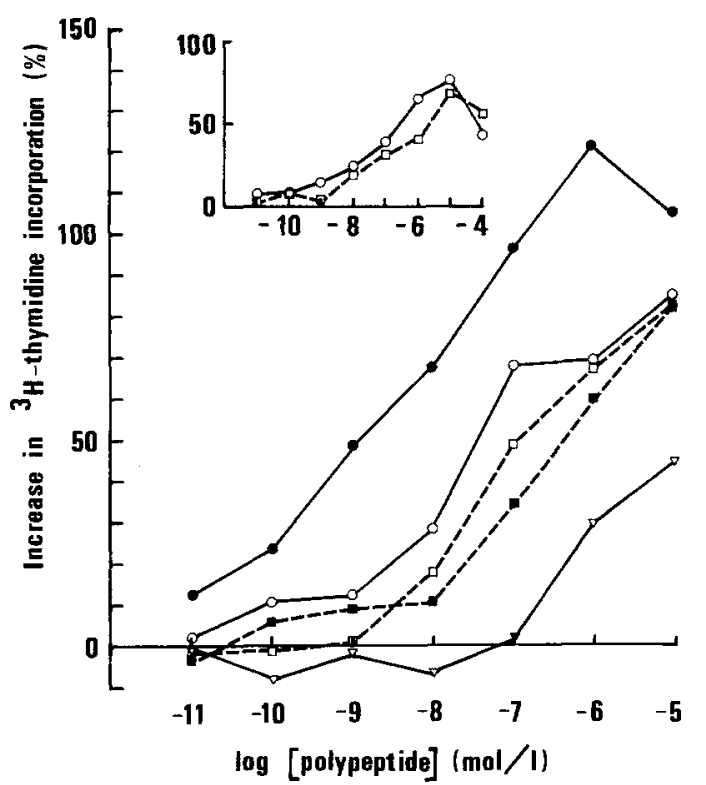

Fig.4. Effect of insulin (O-O), analogue B10 Asp (- $\bullet$ ), analogue B28 Asp ( $\square--\square)$, analogue B9 Asp/B27 Glu (n---a) and proinsulin $(\nabla-\nabla)$ on ${ }^{3} \mathrm{H}$-thymidine incorporation in rat aortic smooth muscle cells. Near-confluent cell cultures were incubated at $37^{\circ} \mathrm{C}$ for $24 \mathrm{~h}$ in F-12 medium in the presence of ${ }^{3} \mathrm{H}$-thymidine and polypeptides. Values are calculated as mean. SEM was less than $21 \%(n=10)$. Insert: Comparison of maximal effects on ${ }^{3} \mathrm{H}$-thymidine incorporation induced by insulin $\left(\mathrm{O}^{\circ} \mathrm{O}\right)$ and B28 Asp $(\square---\square)$. Values are mean of seven different observations

than insulin $\left(\mathrm{EC}_{50}=178 \mathrm{nmol} / \mathrm{l}, \mathrm{pD}_{2}=6.7 \pm 0.2\right)$, while human proinsulin was more than 100 times less potent than insulin (Fig.4).

Time-course studies showed that the effects of both IGF-I and insulin on DNA synthesis were most pronounced when measured $14 \mathrm{~h}$ after addition of the polypeptides. IGF-I $(0.1 \mu \mathrm{mol} / \mathrm{l})$ had a higher maximal effect on DNA synthesis than insulin $(10 \mu \mathrm{mol} / \mathrm{l})$ throughout (Fig.6).

\section{Autoradiography}

The localization of ${ }^{3} \mathrm{H}$-thymidine was exclusively nuclear. Labelling indices were calculated as per cent ${ }^{3} \mathrm{H}$-thymidine-labelled nuclei of total nuclei. IGF-I and insulin significantly increased labelled nuclei compared to control, and the effect of IGF-I was slightly higher than that of insulin. The effects of serum $(0.5 \%)$ and IGF-I or insulin were additive (Table 1).

\section{Cell proliferation studies}

Insulin and IGF-I increased the cell number in the absence of serum, and the effects of insulin and IGF-I were additive to the effect of $0.5 \%$ serum (Table 2). IGF-I and B10 Asp increased cell number slightly more than insulin, although the difference was not statistically significant when using analysis of variance (Table 2).

\section{Degradation of IGF-I and insulin}

The degradation of ${ }^{125}$ I-IGF-I was $47.6 \pm 2.8 \%$ after $24 \mathrm{~h}$ incubation with the cells, whereas the degradation of ${ }^{125} \mathrm{I}$ insulin was $67.8 \pm 1.2 \%(n=8)$. The degradation of ${ }^{125} \mathrm{I}-$ IGF-I and ${ }^{125} \mathrm{I}$-insulin was similar in the presence of different concentrations of unlabelled IGF-I $(0.1 \mathrm{nmol} / \mathrm{l}$ or $0.1 \mu \mathrm{mol} / \mathrm{l})$ or insulin $(0.1 \mathrm{nmol} / 1$ or $1.0 \mu \mathrm{mol} / \mathrm{l})$, respectively.

\section{Discussion}

The results of the present study show that the maximal growth promoting activities of IGF-I, IGF-II and the insulin analogue B10 Asp in vascular smooth muscle are higher than that of insulin.

The binding studies indicate that specific insulin and IGF-I receptors are present in cultured rat aortic smooth muscle cells, and that IGF-I receptors are more abundant than insulin receptors. This is in agreement with results obtained from cultured vascular smooth muscle cells from other species and a cell line derived from embryonic rat

Table 1. Labelling index measurements. The cells were deprived of serum for $24 \mathrm{~h}$, and then incubated in serum, insulin, insulin-like growth factor (IGF-I) or serum-free medium (control) for $24 \mathrm{~h}$. Labelling index was calculated as per cent ${ }^{3} \mathrm{H}$-thymidine-labelled nuclei visualized by autoradiography of total nuclei. Values are given as mean \pm SEM $(n=3)$. Levels of significance (compared to control) were calculated using analysis of variance

\begin{tabular}{lcl}
\hline Treatment & Labelling index & $\begin{array}{l}\text { Level } \\
\text { of significance }\end{array}$ \\
\hline Control & $13.6 \pm 0.5$ & \\
Insulin $1.0 \mu \mathrm{mol} / 1$ & $25.8 \pm 1.2$ & $p \leq 0.05$ \\
IGF-I $0.1 \mu \mathrm{mol} / \mathrm{I}$ & $33.9 \pm 2.3$ & $p \leq 0.001$ \\
Serum $0.5 \%$ & $21.9 \pm 2.4$ & \\
Insulin $1.0 \mu \mathrm{mol} / \mathrm{l}$ & & \\
+ serum $0.5 \%$ & $42.7 \pm 4.2$ & $p \leq 0.001$ \\
IGF-I $0.1 \mu \mathrm{mol} / \mathrm{l}$ & & \\
+ serum $0.5 \%$ & $52.3 \pm 4.7$ & $p \leq 0.001$ \\
Serum $5 \%$ & $79.5 \pm 4.9$ & $p \leq 0.001$ \\
\hline
\end{tabular}

Table 2. Cell number measurements. The cell cultures were deprived of serum for $24 \mathrm{~h}$, and then incubated in serum, insulin, insulin-like growth factor (IGF-I) or serum-free medium (control) for $48 \mathrm{~h}$. The cells were counted in a Bürker chamber. Values are given as mean $\pm S E M$. Levels of significance (compared to control) were calculated using Student's $t$-test. Two different experiments are presented in the table

\begin{tabular}{lcll}
\hline Treatment & $\begin{array}{l}\text { Number of cells } \\
\text { (\% increase) }\end{array}$ & $\begin{array}{l}\text { Level } \\
\text { of significance }\end{array}$ & $n$ \\
\hline Insulin $1.0 \mu \mathrm{mol} / 1$ & $23.6 \pm 10.3$ & & 6 \\
IGF-I 0.1 $\mu \mathrm{mol} / 1$ & $55.2 \pm 14.1$ & $p \leq 0.05$ & 6 \\
$0.5 \%$ serum & $32.0 \pm 10.1$ & $p \leq 0.05$ & 6 \\
Insulin $1.0 \mu \mathrm{mol} / 1$ & & & \\
$+0.5 \%$ serum & $73.4 \pm 19.2$ & $p \leq 0.05$ & 6 \\
IGF-I 0.1 $\mu \mathrm{mol} / 1$ & & & \\
$+0.5 \%$ serum & $87.7 \pm 9.9$ & $p \leq 0.001$ & 6 \\
5\% serum & $125.6 \pm 11.6$ & $p \leq 0.01$ & 6 \\
Insulin $10 \mu \mathrm{mol} / 1$ & $22.7 \pm 4.0$ & $p \leq 0.001$ & 8 \\
B10 Asp $10 \mu \mathrm{mol} / 1$ & $30.6 \pm 3.9$ & $p \leq 0.001$ & 8 \\
IGF-I 0.1 $0 \mathrm{~mol} / 1$ & $33.2 \pm 4.1$ & $p \leq 0.001$ & 8 \\
\hline
\end{tabular}




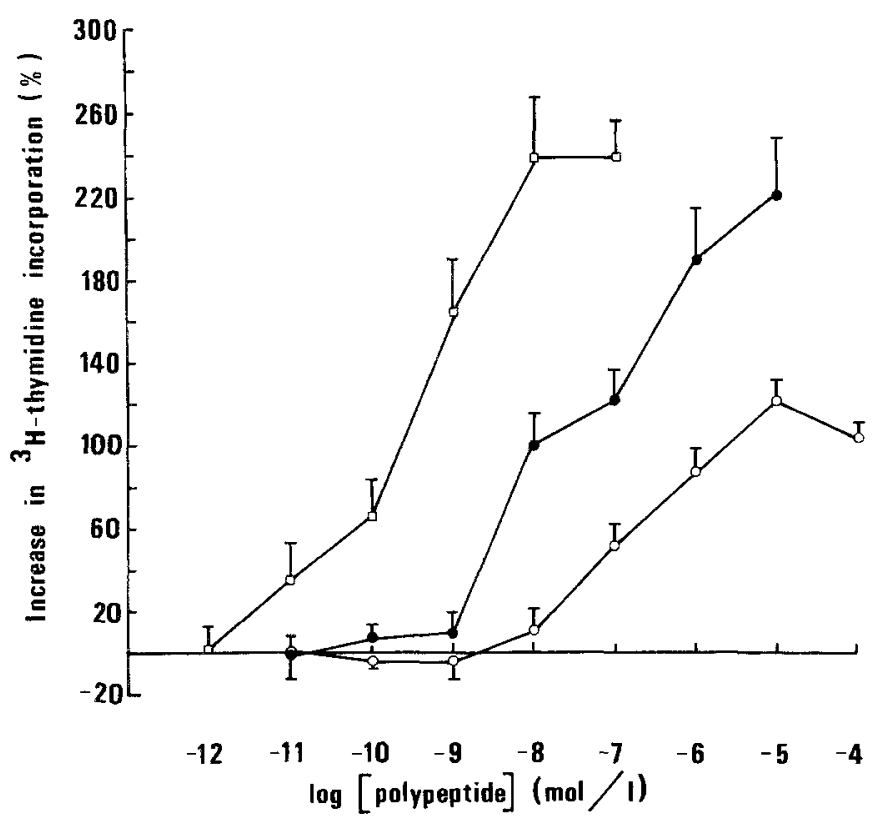

Fig.5. Effect of insulin (O), analogue B10 Asp ( $)$ and insulin-like growth factor-I $(\square)$ on ${ }^{3} \mathrm{H}$-thymidine incorporation in rat aortic smooth muscle cells. Near-confluent cell cultures were incubated at $37^{\circ} \mathrm{C}$ for $24 \mathrm{~h}$ in $\mathrm{F}-12$ medium in the presence of ${ }^{3} \mathrm{H}$-thymidine and polypeptides. Values are calculated as mean $\pm \operatorname{SEM}(n=4)$

aorta $[4,8,9]$. The insulin analogues interacted with both insulin and IGF-I receptors with the following order of potency: B10 Asp > insulin $\geq$ B28 Asp > B9 Asp/B27 Glu. This order of potency has also been shown in a liver cell line of human origin [22].

The $\mathrm{EC}_{50}$-values for IGF-II and insulin on DNA synthesis were approximately 100 times higher than the $\mathrm{EC}_{50^{-}}$ value obtained with IGF-I. One should, however, bear in mind that this method for comparing the relative potency of agonists is most valid if the agonists are capable of eliciting the same maximal response [23]. IGF-I has been shown to be more potent than insulin and IGF-II/multiplication stimulating activity to stimulate DNA synthesis in vascular smooth muscle cells from various sources $[4,8,9]$.
In the present study, the effect of a very high concentration of insulin was not additive to the effects of IGF-I or IGF-II. Furthermore, the effect of IGF-II was not additive to the effect of IGF-I. Receptor studies in the present study and in other studies have shown that insulin $[4,5]$ and IGF-II [9] interact with the IGF-I receptor in vascular smooth muscle cells in concentrations which stimulate DNA synthesis. Taken together, these data suggest that both insulin and IGF-II act via the IGF-I receptor to induce DNA synthesis in these cells. Since the insulin analogues interacted with the IGF-I receptor and were 30 1,800 times less potent than IGF-I to induce DNA synthesis it is probable that also these analogues act via the IGF-I receptor to induce DNA synthesis.

The higher maximal effect of IGF-I and IGF-II than insulin on thymidine incorporation is in agreement with a recent study performed on cultured fetal bovine aortic smooth muscle cells [9]. In the present study the insulin analogue B10 Asp was also found to give a higher maximal stimulation of thymidine incorporation than insulin. Furthermore, the effect of IGF-I on ${ }^{3} \mathrm{H}$-thymidine-labelled nuclei and the effect of IGF-I and B10 Asp on cell number were slightly higher than the effect of insulin, indicating an authentic difference in maximal growth-promoting activity of IGF-I and B10 Asp in comparison with insulin.

How can the higher maximal growth promoting activities of IGF-I and B10 Asp be explained? One possibility could be dimerization/hexamerization of insulin, but not B10 Asp and IGF-I, at high concentrations $(1-100 \mu \mathrm{mol} / \mathrm{l})$, which would reduce the ability to bind to the IGF-I receptor. However, the insulin analogue B28 Asp, which does not form dimers/hexamers [1], did not reach a higher maximal effect on DNA synthesis than insulin. Degradation of insulin was approximately $20 \%$ higher than degradation of IGF-I, and the degradation was constant when different concentrations of insulin or IGF-I were added. Such pattern of degradation would result in a shift of the concentration-effect curve to the right, rather than a lower maximal effect of insulin. Furthermore, IGF-I had a higher maximal effect than insulin throughout the time-course study. A third explana-

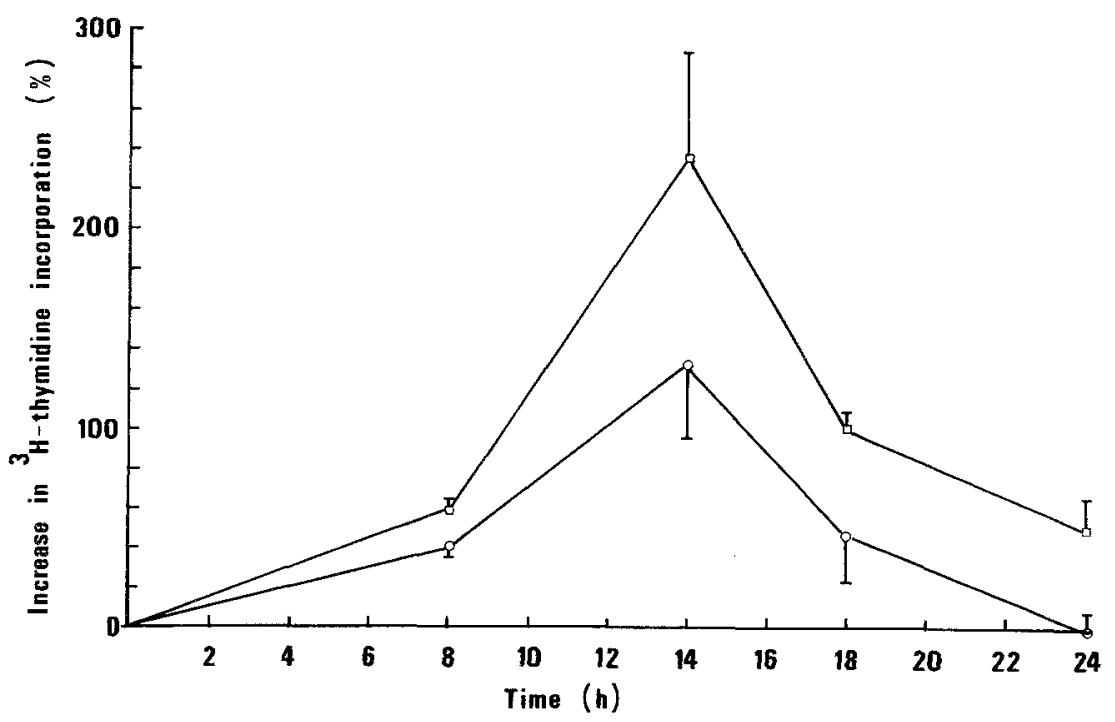

Fig.6. Time-course study on the maximal effects of insulin (O) and insulin-like growth factor-I ( $\square$ ) on ${ }^{3} \mathrm{H}$-thymidine incorporation in rat aortic smooth muscle cells. Near-confluent cell cultures were incubated in the presence of polypeptides at $37^{\circ} \mathrm{C}$ for $6,12,16$, or $22 \mathrm{~h} .{ }^{3} \mathrm{H}$-thymidine was present during an additional $2 \mathrm{~h}$ incubation. Values are mean $\pm \operatorname{SEM}(n=4)$ 
tion could be that IGF-binding proteins secreted by the smooth muscle cells would increase the effect of IGF-I on DNA synthesis. A low-molecular weight IGF-binding protein purified from human amniotic fluid has been reported to increase the effect of IGF-I, but not of insulin, on DNA synthesis in aortic smooth muscle cells, [24]. It was suggested that the increased effect of IGF-I in the presence of the binding protein was due to an enhanced binding of IGF-I to the receptor. Cultured vascular smooth muscle cells have been found to secrete IGF-binding proteins [27], but these binding proteins did not increase the cellular binding of IGF-I [28]. Several other studies have shown that the action of IGF-I and IGF-II is inhibited by low-molecular weight binding proteins $[25,26]$. The difference in maximal growth promoting activities between insulin and B10 Asp and IGF-I, therefore, do not seem to be due to either dimerization/hexamerization or degradation and it seems unlikely that it is due to interaction with IGF-binding proteins.

A compound that produces a response less than maximum even when occupying nearly all of the receptors is termed a partial agonist [29]. One could speculate that insulin acts as a partial agonist on the IGF-I receptor in these cells, whereas IGF-I and IGF-II act as full agonists. The reason for this is unknown, but the fact that analogue B10 Asp also induced a higher maximum than insulin may give a clue. Human insulin, as well as porcine and bovine insulin, has a basic amino acid in position B10 (His), whereas IGFs have an acidic amino acid (Glu) in the corresponding position. Thus, changing the amino acid in position B10 from a basic to an acidic amino acid (Asp) in analogue B10 Asp makes the analogue chemically more similar to IGF-I. Residue B10 is located just outside the receptor-binding region [1]. It is possible that this residue, at least partly, is responsible for the lower maximal response on DNA synthesis induced by insulin in comparison with IGF-I.

Whether the difference in growth effects between insulin, IGF-I and the insulin analogue B10 Asp could be of any clinical importance is presently an open question.

Acknowledgements. We are grateful to NovoNordisk a/s, Denmark, for the generous gift of insulin analogues and human proinsulin. Financial support was given by Nordisk Insulinfond, the Swedish Diabetes Association, the Swedish Hoechst Diabetes Fund, Lion's Scholarship for Medical Research, the Swedish Society for Medical Research and the Swedish Medical Research Council (4952 and 4486).

\section{References}

1. Brange J, Ribel U, Hansen JF, Dodson G, Hansen MT, Havelund S, Melberg SG, Norris F, Norris K, Snel L, Sørensen AR, Voigt HO (1988) Monomeric insulins obtained by protein engineering and their medical implications. Nature 333: 679-682

2. Ullrich A, Bell JR, Chen EY, Herrera R, Petruzzelli LM, Dull TJ, Gray A, Coussens L, Liao Y-C, Tsubokawa M, Mason A, Seeburg PH, Grundfeld C, Rosen OM, Ramachandran J (1985) Human insulin receptor and its relationship to the tyrosine kinase family of oncogenes. Nature 313: 756-761
3. Ullrich A, Gray A, Tam AW, Yang-Feng T, Tsubokawa M, Collins C, Henzel W, Le Bon T, Kathuria S, Chen E, Jacobs S, Francke U, Ramachandran J, Fujita-Yamaguchi Y (1986) Insulin-like growth factor I receptor primary structure: comparison with insulin receptor suggests structural determinants that define functional specificity. EMBO J 5: 2503-2512

4. King GL, Goodman AD, Buzney S, Moses A, Kahn CR (1985) Receptors and growth-promoting effects of insulin and insulinlike growth factors on cells from bovine retinal capillaries and aorta. J Clin Invest 75: 1028-1036

5. Bornfeldt KE, Arnqvist HJ, Dahlkvist HH, Skottner A, Wikberg JES (1988) Receptors for insulin-like growth factor-I in plasma membranes isolated from bovine mesenteric arteries. Acta Endocrinol 117: 428-434

6. Pfeifle B, Ditschuneit HH, Ditschuneit H (1982) Binding and biological actions of insulin-like growth factors on human arterial smooth muscle cells. Horm Metab Res 14: 409-414

7. Kaiser N, Tur-Sinai A, Hasin M, Cerasi E (1985) Binding, degradation, and biological activity of insulin in vascular smooth muscle cells. Am J Physiol 249: E292-E298

8. Cascieri MA, Chicchi GG, Hayes NS, Slater EE (1986) Stimulation of DNA synthesis in rat A10 vascular smooth muscle cells by threonine-59 insulin-like growth factor-I. Circ Res 59: 171-177

9. Lee PDK, Hintz RL, Rosenfeld RG, Benitz WE (1988) Presence of insulin-like growth factor receptors and lack of insulin receptors on fetal bovine smooth muscle cells. In Vitro Cell Devel Biol 24: 921-926

10. Stout RW (1987) Insulin and atheroma - an update. Lancet I: $1077-1079$

11. King GL (1985) Cell biology as an approach to the study of the vascular complications of diabetes. Metabolism 34 [Suppl. 1]: $17-24$

12. Nilsson J, Ksiazek T, Heldin C-H, Thyberg J (1983) Demonstration of stimulatory effects of platelet-derived growth factor on cultivated rat arterial smooth muscle cells. Exp Cell Res 145 : 231-237

13. Ham RG (1965) Clonal growth of mammalian cells in a chemically defined, synthetic medium. Proc Natl Acad Sci USA 53: 288-293

14. Ross R (1971) The smooth muscle cell. II. Growth of smooth muscle in culture and formation of elastic fibers. J Cell Biol 50: $172-186$

15. Skalli O, Ropraz P, Trzeciak A, Benzonana G, Gillssen D, Gabbiani $G$ (1986) A monoclonal antibody against $\alpha$-smooth muscle actin: a new probe for smooth muscle differentiation. J Cell Biol 103: 2787-2796

16. Nilsson J, Thyberg J (1982) Fine structure of arterial smooth muscle cells cultured in the presence of whole blood serum or plasma-derived serum. Cell Tissue Res 223: 87-99

17. Nilsson J, Ksiazek T, Thyberg J (1983) Effects of colchicine on DNA synthesis, endocytosis and fine structure of cultivated arterial smooth muscle cells. Exp Cell Res 143:367-375

18. Goldstein JL, Brown MS (1974) Binding and degradation of lowdensity lipoproteins by cultured human fibroblasts. J Biol Chem 249: 5153-5162

19. Skottner A, Fryklund L, Hansson HA (1986) Experimental research on IGF-I. Acta Paediatr Scand 325: 107-111

20. Waud DR (1975) Analysis of dose-response curves. In: Daniel EE, Paton DM (eds) Methods in pharmacology, Vol 3. Plenum Press, New York, pp 471-506

21. Marquardt DW (1963) An algorithm for Ieast-squares estimation of non-linear parameters. J Soc Indust Appl Math 11: 431-441

22. Drejer K, Kruse V, Larsen UD (1988) Insulin analogs: binding to the human liver cell line, HEP G2. Diabetes Res Clin Pract 5 [Suppl 1]: 231

23. Limbird $\mathrm{E}$ (1986) Cell surface receptors: a short course on theory and methods, 3rd edn. Martinus Nijhoff, Boston

24. Elgin RG, Busby WH Jr, Clemmons DR (1987) An insulin-like growth factor (IGF) binding protein enhances the biologic response to IGF-I. Proc Natl Acad Sci USA 84: 32543258 
25. Ross M, Francis GL, Szabo L, Wallace JC, Ballard FJ (1989) Insulin-like growth factor (IGF)-binding proteins inhibit the biological activities of IGF-1 and IGF-2 but not des-(1-3)-IGF-1. Biochem J 258:267-272

26. Ritvos O, Ranta T, Jalkanen J, Suikkari A-M, Voutilainen R, Bohn H, Rutanen E-M (1988) Insulin-like growth factor (IGF) binding protein from human decidua inhibits the binding and biological action of IGF-I in cultured choriocarcinoma cells. Endocrinology 122: 2150-2157

27. McCusker RH, Clemmons DR (1988) Insulin-like growth factor binding protein secretion by muscle cells: effect of cellular differentiation and proliferation. J Cell Physiol 137: 505-512

28. Clemmons DR, Elgin RG, Han VKM, Casella SJ, D'Ercole AJ, Van Wyk JJ (1986) Cultured fibroblast monolayers secrete a pro- tein that alters the cellular binding of somatomedin-C/insulinlike growth factor I. J Clin Invest 77: 1548-1556

29. Bowman WC, Rand MJ (1980) Principles of drug action. In: Textbook of pharmacology, 2nd English edn. Blackwell Scientific Publications, Oxford, pp 1.39-69

Received: 4 December 1990

Dr. K. Bornfeldt

Department of Pharmacology

Linköping University

Regionsjukhuset

S-581 85 Linköping

Sweden 